\title{
Manganese incorporation in living (stained) benthic foraminiferal shells: a bathymetric and in-sediment study in the Gulf of Lions (NW Mediterranean)
}

\author{
Shauna Ní Fhlaithearta ${ }^{1}$, Christophe Fontanier ${ }^{2,3,4}$, Frans Jorissen ${ }^{5}$, Aurélia Mouret ${ }^{5}$, Adriana Dueñas-Bohórquez ${ }^{1}$, \\ Pierre Anschutz ${ }^{2}$, Mattias B. Fricker ${ }^{6}$, Detlef Günther ${ }^{6}$, Gert J. de Lange ${ }^{1}$, and Gert-Jan Reichart ${ }^{1,7}$ \\ ${ }^{1}$ Faculty of Geosciences, Utrecht University, Utrecht, the Netherlands \\ ${ }^{2}$ EPOC, UMR CNRS 5805, University of Bordeaux, Pessac, France \\ ${ }^{3}$ FORAM, Foraminiferal Study Group, 29200, Brest, France \\ ${ }^{4}$ Faculty of Sciences, Université d'Angers, Angers, France \\ ${ }^{5}$ Université d'Angers, LPG-BIAF, UMR CNRS 6112, 49045 Angers Cedex, France \\ ${ }^{6}$ Laboratory of Inorganic Chemistry, ETH Zurich, 8093 Zurich, Switzerland \\ ${ }^{7}$ Royal Netherlands Institute of Sea Research, Landsdiep 4, 1797 SZ 't Horntje, the Netherlands
}

Correspondence: Shauna Ní Fhlaithearta (s.ni.fhlaithearta@gmail.com)

Received: 23 January 2018 - Discussion started: 5 March 2018

Revised: 26 July 2018 - Accepted: 27 July 2018 - Published: 26 October 2018

\begin{abstract}
Manganese geochemistry in deep-sea sediments is known to vary greatly over the first few centimeters, which overlaps the in-sediment depth habitats of several benthic foraminiferal species. Here we investigated manganese incorporation in benthic foraminiferal shell carbonate across a six-station depth transect in the Gulf of Lions, NW Mediterranean, to unravel the impacts of foraminiferal ecology and Mn pore water geochemistry. Over this transect water depth increases from 350 to $1987 \mathrm{~m}$, while temperature $\left(\sim 13{ }^{\circ} \mathrm{C}\right)$ and salinity $(\sim 38.5)$ remained relatively constant. Manganese concentrations in the tests of living (rose bengal stained) benthic foraminiferal specimens of Hoeglundina elegans, Melonis barleeanus, Uvigerina mediterranea, and Uvigerina peregrina were measured using laser ablation inductively coupled mass spectrometry (laser ablation ICPMS). Pore water manganese concentrations show a decrease from shallow to deeper waters, which corresponds to a generally decreasing organic-matter flux with water depth. Differences in organic-matter loading at the sediment-water interface affects oxygen penetration depth into the sediment and hence Mn pore water profiles. Mn / Ca values for the investigated foraminiferal species reflect pore water geochemistry and species-specific microhabitat in the sediment. The observed degree of variability within a single species is in line with known ranges in depth habitat and gradients in redox
\end{abstract}

conditions. Both the $\mathrm{Mn} / \mathrm{Ca}$ ratio and interspecific variability hence reflect past Mn cycling and related early diagenetic processes within the sediment, making this a potential tool for bottom-water oxygenation and organic-matter fluxes. Dynamics of both in-sediment foraminiferal depth habitats and Mn cycling, however, limit the application of such a proxy to settings with relatively stable environmental conditions.

\section{Introduction}

Reconstructing past climate and environmental change largely depends on so-called proxies. These proxies relate measurable variables in the geological record to target parameters, such as temperature, biological productivity, and bottom-water oxygenation. The carbonate shells of unicellular protists, foraminifera, are one of the most utilized signal carriers for reconstructing past environments. Both the census data of foraminifera and the geochemical composition of the shells are used in this context. The geochemical composition of the shells is investigated for their stable isotopic composition as well as for their trace and minor element incorporation. Both pelagic and bottom-water conditions are recon- 
structed this way using planktonic and benthic foraminiferal species, respectively.

Most existing calibrations of trace element uptake in foraminiferal test carbonate are based on comparing their composition with bottom-water conditions (Elderfield et al., 2006; Nürnberg et al., 1996; Yu and Elderfield, 2007). Many benthic foraminiferal species live, however, within the sediment and precipitate their calcium carbonate test in contact with pore water. As a result, the trace metal composition of pore water exerts a control on the uptake of trace metals in their test. This effectively links benthic foraminiferal microhabitat preference and pore water chemistry. On the one hand, this creates complications when using foraminiferal trace metal ratios for reconstructing bottom-water conditions; on the other hand, it offers the possibility to develop proxies for pore water chemistry in the past.

Linking foraminiferal test chemistry with pore water chemistry requires in-depth knowledge of (1) how early diagenesis in sediments affects pore water chemistry, (2) the habitat preference of the foraminiferal species, and (3) foraminiferal migration (and the depth at which they calcify) within the uppermost sediment layer. In principle, the chemical composition of living (stained) benthic foraminifera will reflect all these processes.

For many elements an important interspecific difference in the uptake of trace metals has been observed (Hintz et al., 2006; Wit et al., 2012; Barras et al., 2018), a so-called vital effect. This implies that in addition to ecology and pore water geochemistry, trace metal partitioning also needs to be taken into consideration. This requires a comparative study between locations where all three of these aspects have been quantified.

Reconstructing past pore water trace metal profiles is important since it provides valuable information on organic carbon degradation and the recycling of nutrients at the seafloor (Van Cappellen and Wang, 1996; De Lange, 1986). Such diagenetically controlled trace metal profiles are used in quantitative models constraining oceanic carbon fluxes and burial (Wang and Van Cappellen, 1996). Knowledge of such profiles in the past could thus help us to reconstruct past carbon cycles.

Benthic foraminiferal species have a specific preference for their depth habitat (Jorissen et al., 1995). Some benthic foraminiferal species are limited to a very narrow environmental in-sediment range, for example along redox fronts, whereas others have a wider distribution, thriving under variable conditions and consequently occupying a broader niche. These differences in depth habitat preferences could be related to the presence of different types of metabolism (Koho et al., 2011; Risgaard-Petersen et al., 2006). As such, trace metal profiles and foraminiferal in-sediment depth habitat can be related, as recently proposed in a conceptual $\left(\right.$ TROXCHEM $^{3}$ ) model for the redox-sensitive element manganese by Koho et al (2015). Studying the interplay between benthic foraminiferal habitat preference and the incorpora-

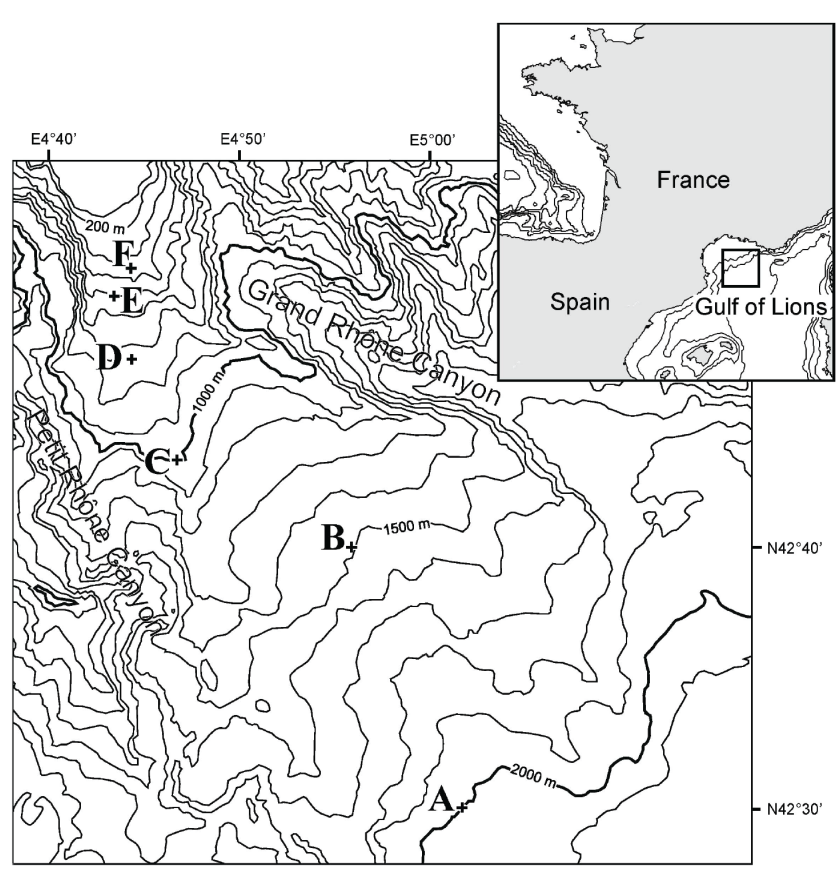

Figure 1. Location map showing sampling stations and bathymetry.

tion of redox-sensitive trace elements is key to verifying such models.

Studying manganese bound in foraminiferal shell carbonate lies at the intersection of foraminiferal ecology and early diagenesis in sediments. Manganese is a redox-sensitive element and exists as Mn (hydr)oxides in the presence of oxygen. As oxygen concentrations in the sediment decrease due to ongoing organic-matter remineralization, $\mathrm{Mn}$ (hydr)oxides are reduced to aqueous $\mathrm{Mn}^{2+}$ (Froelich et al., 1979). Manganese in sediments continuously cycles between the solid and aqueous state as a result of the upward diffusion of $\mathrm{Mn}^{2+}$ and consequent remineralization to Mn (hydr)oxides. Hence, proxy studies must account for both ecological controls, like foraminiferal habitat preference, and geochemical controls like oxygen concentrations and organic-matter loading (Glock et al., 2012; Groeneveld and Filipsson, 2013; Koho et al., 2015, 2017; McKay et al., 2015; Reichart et al., 2003). Notably, both benthic foraminifera and trace metal geochemistry react to organic-matter recycling and bottom-water oxygenation (Jorissen et al., 1995). This implies that locations with contrasting conditions, both low and high bottom-water oxygenation as well as low and high productivity, are required for testing. Whereas most of these studies focused on the role of bottom-water oxygenation in relatively oxygen poor settings, here we focus on the well-oxygenated western Mediterranean.

In this study we combine pore water geochemistry, foraminiferal habitat preference, and test geochemistry in an area characterized by well-oxygenated bottom-water conditions and average productivity. Results are compared with 
Table 1. Water depth, coordinates, and bottom-water physiochemical parameters: temperature $\left({ }^{\circ} \mathrm{C}\right)$, salinity, and oxygen penetration depth $(\mathrm{mm})$ for six stations F-A.

\begin{tabular}{lrrrrrr}
\hline Station & Depth (m) & Latitude (N) & Longitude (E) & $\begin{array}{r}\text { Bottom-water } \\
\text { temperature* }\left({ }^{\circ} \mathrm{C}\right)\end{array}$ & $\begin{array}{r}\text { Bottom-water } \\
\text { salinity* }\end{array}$ & $\begin{array}{r}\text { Oxygen penetration } \\
\text { depth }(\mathrm{mm})\end{array}$ \\
\hline $\mathrm{F}$ & 350 & $42^{\circ} 52^{\prime} 32$ & $4^{\circ} 42^{\prime} 43$ & 13.2 & $\sim 38.5$ & $20.5 \pm 3.3$ \\
$\mathrm{E}$ & 552 & $42^{\circ} 48^{\prime} 78$ & $4^{\circ} 43^{\prime} 21$ & 13.2 & $\sim 38.5$ & $57.2 \pm 4.5$ \\
$\mathrm{D}$ & 745 & $42^{\circ} 46^{\prime} 66$ & $4^{\circ} 43^{\prime} 91$ & 13.1 & $\sim 38.5$ & $36.5 \pm 1.6$ \\
$\mathrm{C}$ & 980 & $42^{\circ} 43^{\prime} 18$ & $4^{\circ} 46^{\prime} 58$ & 13.1 & $\sim 38.48$ & $50.7 \pm 6.3$ \\
$\mathrm{~B}$ & 1488 & $42^{\circ} 38^{\prime} 83$ & $4^{\circ} 56^{\prime} 03$ & 13.1 & $\sim 38.46$ & $141.5 \pm 0.0$ \\
$\mathrm{~A}$ & 1987 & $42^{\circ} 28^{\prime} 25$ & $5^{\circ} 00^{\prime} 61$ & 13.1 & $\sim 38.46$ & $197.0 \pm 11.0$ \\
\hline
\end{tabular}

* Xavier Durrieu de Madron, personal communication, 2006.

earlier studies from high productivity regimes and low oxygen conditions at the sediment-water interface (e.g., Arabian Sea; Koho et al., 2015; Mediterranean sapropel deposition, Ní Fhlaithearta et al., 2010). Specifically, we investigate the link between manganese incorporation and benthic foraminiferal ecology and compare this to the recently proposed TROXCHEM ${ }^{3}$ model (Koho et al., 2015). Four species of living (stained) foraminifera were sampled along a six-station bathymetric transect in the Gulf of Lions, NW Mediterranean. Individuals were picked from a series of insediment depths and analyzed by laser ablation ICP-MS, enabling multiple analyses of single specimens.

\section{Material and methods}

\subsection{Study area and sediment sampling}

Cores were collected with a classical Barnett multicorer (Barnett et al., 1984) at six stations in the Gulf of Lions (NW Mediterranean) during the August-September 2006 BEHEMOTH cruise (Fig. 1, Table 1). The six stations describe a bathymetric transect from 350 to $1987 \mathrm{~m}$ of depth. The shallowest site, station F, is bathed in Mediterranean Intermediate Water (MIW). Stations E (552 m) and D (745 m) are positioned at the transition of MIW and Western Mediterranean Deep Water (WMDW). Stations C (980 m), B (1488 m), and A $(1987 \mathrm{~m})$ are bathed by the WMDW. Bottom-water temperature is stable through the part of the water column studied here $\left(\sim 13.1^{\circ} \mathrm{C}\right)$ (Xavier Durrieu de Madron, personal communication, 2006). Salinity ranges between 38.4 and 38.5. The multicorer allowed for sampling of the first decimeters of the sediment, the overlying bottom waters, and an undisturbed sediment-water interface. Cores were sliced for foraminiferal studies with a $0.5 \mathrm{~cm}$ resolution down to $4 \mathrm{~cm}$, followed by $1 \mathrm{~cm}$ slices down to $10 \mathrm{~cm}$ of depth. Sediments were put in an ethanol-rose bengal mixture $(95 \%$ ethanol with $1 \mathrm{~g} \mathrm{~L}^{-1}$ rose bengal) in order to identify living (stained) specimens. For more detailed information about methods, please consult Fontanier et al. (2008).

\subsection{Pore water geochemistry}

Sediment sampling for pore water extraction was carried out under an inert atmosphere $\left(\mathrm{N}_{2}\right)$. Thereafter, samples were centrifuged at $3500 \mathrm{rpm}$ for $20 \mathrm{~min}$. The supernatant was filtered and acidified $\left(\mathrm{HNO}_{3}\right.$ suprapure) for analyzing dissolved metals. Dissolved Mn concentrations were determined with flame atomic absorption spectrometry (PerkinElmer AA 300). The precision for this method is $\pm 5 \%$. A pore water subsample was also analyzed for $\mathrm{Mn}$ using ICP-MS (Agilent 7500 series). The relative precision for this method is $3 \%$. The total alkalinity of pore water was measured at Utrecht University using an automated titrator (702 SM Titrino, Metrohm) making Gran plots. Dissolved inorganic carbon (DIC) was measured using a dissolved carbon analyzer (Shimadzu, Model TOC-5050A). Carbonate ion concentrations were calculated using the CO2SYS software (version 01.05; Lewis and Wallace, 1998). Analytical uncertainty for the alkalinity is about $10 \mu \mathrm{eq}$, and the relative standard deviation for the DIC analyses is $0.8 \%$.

Oxygen concentration profiles were determined using Clark-type microelectrodes (Unisense $\odot$, Denmark). Labile organic matter was derived from the sum of lipids, amino acids, and sugars measured in the top centimeter of sediment; for details, see Fontanier et al. (2008).

\subsection{Foraminiferal trace metal geochemistry}

Foraminiferal trace element concentrations were determined using two laser ablation ICP-MS systems. Prior to laser ablation, all samples were gently cleaned in methanol $(x 1)$ and UHQ water $(x 4)$. Between each rinse, the samples were placed in a sonic bath for several seconds to thoroughly clean the tests. Benthic foraminifera from $745 \mathrm{~m}$ (station D), $980 \mathrm{~m}$ (station C), $1488 \mathrm{~m}$ (station B), and $1987 \mathrm{~m}$ (station A) were measured at Utrecht University using a deep UV (193 nm) ArF excimer laser (Lambda Physik) with GeoLas 200Q optics. Ablation was performed at a pulse repetition rate of $10 \mathrm{~Hz}$ and an energy density of $1.4 \mathrm{~J} \mathrm{~cm}^{-2}$, with a crater size of $80 \mu \mathrm{m}$. Ablated particles were measured by a quadrupole ICP-MS (Micromass Platform) equipped with a collision and 


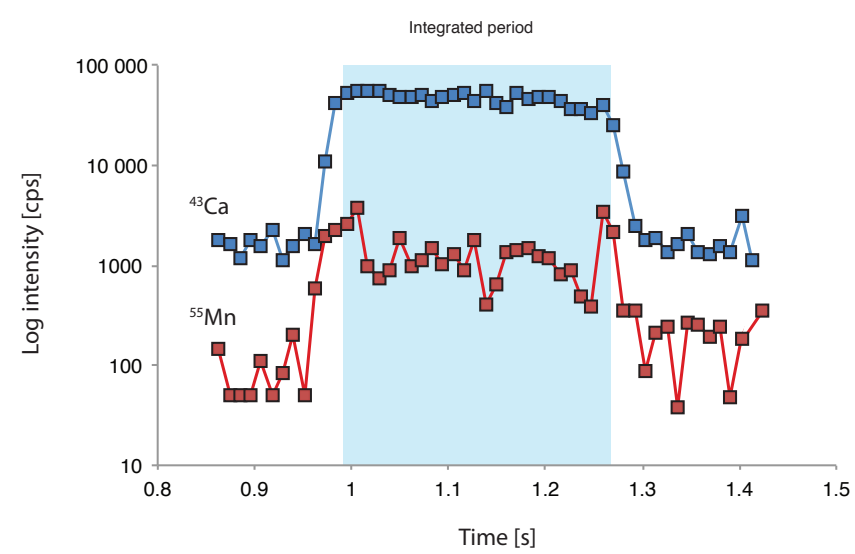

Figure 2. Example of a laser ablation profile with signal log intensity counts per second (cps) through time. The integrated signal is shaded.

reaction cell. Such a collision and reaction cell improves carbonate analyses by eliminating interferences on mass 44 . Scanned masses included ${ }^{24} \mathrm{Mg},{ }^{26} \mathrm{Mg},{ }^{27} \mathrm{Al},{ }^{42} \mathrm{Ca},{ }^{43} \mathrm{Ca}$, ${ }^{55} \mathrm{Mn},{ }^{88} \mathrm{Sr},{ }^{137} \mathrm{Ba},{ }^{138} \mathrm{Ba}$, and ${ }^{208} \mathrm{~Pb}$. Benthic foraminifera from stations $\mathrm{F}(350 \mathrm{~m})$ and $\mathrm{E}(552 \mathrm{~m})$ were analyzed at ETH Zurich (due to laboratory renovations at Utrecht University). The laser type and ablation parameters were identical to those detailed above. The ablated particles were measured using a quadrupole ICP-MS (ELAN 6100 DRC, PerkinElmer). In both cases, calibration was performed using an international standard (NIST610) with $\mathrm{Ca}$ as an internal standard (Jochum et al., 2011). The same masses as measured in Utrecht were monitored, in addition to ${ }^{7} \mathrm{Li},{ }^{23} \mathrm{Na}$, ${ }^{47} \mathrm{Ti},{ }^{60} \mathrm{Ni},{ }^{61} \mathrm{Ni}$, and ${ }^{89} \mathrm{Y}$. Interlaboratory compatibility was monitored using a matrix-matched calcite standard. For Mn this standard showed a precision better than $3 \%$ over all analyses, at ETH and UU, and with an offset of less than $5 \%$ from an offline-determined (solution ICP-AES) concentration analyzing discrete subsamples. The matrix-matched standard is routinely included in the analyses and has been monitored since 2010 (Duenas Bohorquez et al., 2011).

Analytical error (equivalent to $1 \sigma$ ), based on repeated measurement of an external standard, was $<5 \%$ for reported elements. Each laser ablation measurement was screened for contamination by monitoring $\mathrm{Al}$ and $\mathrm{Pb}$. On encountering surface contamination, the data integration interval was adjusted to exclude any $\mathrm{Al}$ or $\mathrm{Pb}$ enrichment. Cross-plots between $\mathrm{Al}$ and $\mathrm{Pb}$ versus $\mathrm{Mn}$ showed that they are unrelated, confirming the accuracy of the integrations.

During the laser ablation analyses the different trace elements were monitored with respect to time, thus representing a cross section of the test wall. This allows for not only quantification of the different trace metals of interest, but also observation of the variability within individual tests. Each species has a distinct test-wall thickness, permitting the study of intra-test variability. A typical ablation profile for $\mathrm{H}$. elegans is shown in Fig. 2.

\subsection{Analyses of manganese in foraminiferal tests}

Contamination and the presence of secondary Mn-rich coatings on benthic foraminiferal tests has been a longstanding challenge in trace metal analyses of benthic foraminifera (Boyle, 1983; Lea and Boyle, 1989). In this study the trace metal data are based exclusively on living (rose bengal stained) foraminifera, which effectively rules out the impact of Mn-rich coatings on trace metal concentrations. At the time of sampling, the collected tests were still enveloped by foraminiferal cytoplasm, preventing the formation of extraneous inorganic precipitates. Although benthic foraminifera live within the sediment, their test is physically separated from the environment as they are enveloped in an organic sheath (Ní Fhlaithearta et al., 2013). In the case that a recently deceased foraminifer was mistakenly analyzed (still with sufficient protoplasm to stain with rose bengal) the $\mathrm{Mn}$ oxide would not only have had limited time to develop, but it would also show up as an Mn spike at the start of a laser ablation profile. The ablation profiles confirm that no Mn-rich phases are present at the test surfaces (Fig. 2).

Comparing LA-ICP-MS data with traditional solution analyses for foraminiferal $\mathrm{Mg} / \mathrm{Ca}$ values showed that data are directly comparable (Rosenthal et al., 2011). Also for trace metals such as $\mathrm{Ni}^{2+}, \mathrm{Cu}^{2+}$, and $\mathrm{Mn}^{2+}$, crosscalibration of LA-ICP-MS and micro-XRF shows that those analytical results are robust (Munsel et al., 2010).

\subsection{Benthic foraminiferal Mn / Ca}

Manganese incorporation in benthic foraminiferal test carbonate was analyzed from four different species (Hoeglundina elegans, Melonis barleeanus, Uvigerina mediterranea, Uvigerina peregrina) from six coring sites for up to nine depths in the sediment. Sample coverage for all stations is described in Table 2. Descriptive statistics are presented in Table 3.

From the largest taxon, Uvigerina mediterranea, three to four analyses were routinely carried out per test, and no trend in $\mathrm{Mn} / \mathrm{Ca}$ values was seen in consecutive growth stages. From the other species two analyses were performed per test. The resolution of the ablation profiles themselves does not allow for the quantification of changes in trace metals within the test wall. Still, comparing the data within individual ablation profiles shows that the intra-test variability is generally limited for Mn (Table 4). As the ablation profiles target one chamber mostly, this does not include the full potential range. Comparing different ablation profiles between chambers in a single shell would circumvent this, but these data are somewhat limited.

Box plots are used to describe the range of $\mathrm{Mn} / \mathrm{Ca}$ values and how the distribution, median, average, and skewness 
Table 2. Number of LA-ICP-MS analyses per benthic foraminifera species per sample per station.

\begin{tabular}{|c|c|c|c|c|c|c|}
\hline Station & $\begin{array}{r}\text { Depth } \\
(\mathrm{m})\end{array}$ & $\begin{array}{r}\text { Sample } \\
\text { intervals } \\
(\mathrm{cm})\end{array}$ & $\begin{array}{r}\text { Hoeglundina } \\
\text { elegans } \\
\text { no. analyses }\end{array}$ & $\begin{array}{r}\text { Uvigerina } \\
\text { mediterranea } \\
\text { no. analyses }\end{array}$ & $\begin{array}{r}\text { Uvigerina } \\
\text { peregrina } \\
\text { no. analyses }\end{array}$ & $\begin{array}{r}\text { Melonis } \\
\text { barleeanus } \\
\text { no. analyses }\end{array}$ \\
\hline \multirow[t]{7}{*}{$\mathrm{F}$} & 350 & $0-0.5$ & 2 & 18 & 5 & 1 \\
\hline & & $0.5-1$ & 4 & 13 & & 2 \\
\hline & & $1-1.5$ & & 3 & & \\
\hline & & $1.5-2$ & & & & 10 \\
\hline & & $2-2.5$ & 1 & & & 2 \\
\hline & & $3-3.5$ & & & & 3 \\
\hline & & 5-6 & & & & 3 \\
\hline \multirow[t]{10}{*}{ E } & 552 & $0-0.5$ & & 5 & 26 & \\
\hline & & $0.5-1$ & & & 9 & 4 \\
\hline & & $1-1.5$ & & & 14 & 3 \\
\hline & & $1.5-2$ & & & 5 & 3 \\
\hline & & $2-2.5$ & & & 7 & 3 \\
\hline & & $2.5-3$ & & & 6 & 2 \\
\hline & & $3-3.5$ & & & 6 & \\
\hline & & $3.5-4$ & & & 8 & 1 \\
\hline & & 4-5 & & 3 & & \\
\hline & & 7-8 & & & & 1 \\
\hline \multirow[t]{8}{*}{ D } & 745 & $0-0.5$ & & 20 & 13 & \\
\hline & & $0.5-1$ & & 6 & & 5 \\
\hline & & $1-1.5$ & & 3 & 6 & \\
\hline & & $1.5-2$ & & 7 & 8 & 6 \\
\hline & & $2-2.5$ & & & 4 & \\
\hline & & $3.5-4$ & & & 2 & \\
\hline & & 4-5 & & & 2 & 4 \\
\hline & & $8-9$ & & & 2 & \\
\hline \multirow[t]{3}{*}{$\mathrm{C}$} & 980 & $0-0.5$ & & 20 & & 2 \\
\hline & & $0.5-1$ & & 20 & & 2 \\
\hline & & $1-1.5$ & & 4 & & \\
\hline \multirow[t]{2}{*}{ B } & 1488 & $0-0.5$ & 3 & 4 & 10 & 4 \\
\hline & & $0.5-1$ & 9 & 5 & 3 & 5 \\
\hline \multirow[t]{2}{*}{ A } & 1987 & $0-0.5$ & 15 & & 10 & \\
\hline & & $1-1.5$ & & & & 3 \\
\hline
\end{tabular}

Table 3. Descriptive statistics (minimum, maximum, mean, median, standard deviation, and interval of maximum frequency of total analyses for H. elegans, U. mediterranea, U. peregrina, and M. barleeanus for $\mathrm{Mn} / \mathrm{Ca} \mu \mathrm{mol} \mathrm{mol}^{-1}$ ).

\begin{tabular}{lrrrr}
\hline Mn / Ca $\mu \mathrm{mol} \mathrm{mol}^{-1}$ & H. elegans & U. mediterranea & U. peregrina & M. barleeanus \\
\hline Min. & $\mathrm{DL}^{*}$ & $\mathrm{DL}$ & $\mathrm{DL}$ & 3.91 \\
Max. & 0.69 & 22.71 & 35.38 & 149.50 \\
Mean & 0.04 & 4.03 & 8.28 & 37.22 \\
Median & $\mathrm{DL}^{*}$ & 1.04 & 7.45 & 24.76 \\
SD & 0.16 & 5.03 & 7.17 & 35.17 \\
Max. frequency interval & $\mathrm{DL}-7.50(100 \%<1)$ & $\mathrm{DL}-7.50(80 \%)$ & $\mathrm{DL}-7.50(53 \%)$ & $7.5-15(23 \%)$ \\
\hline
\end{tabular}

* DL: detection limit. 

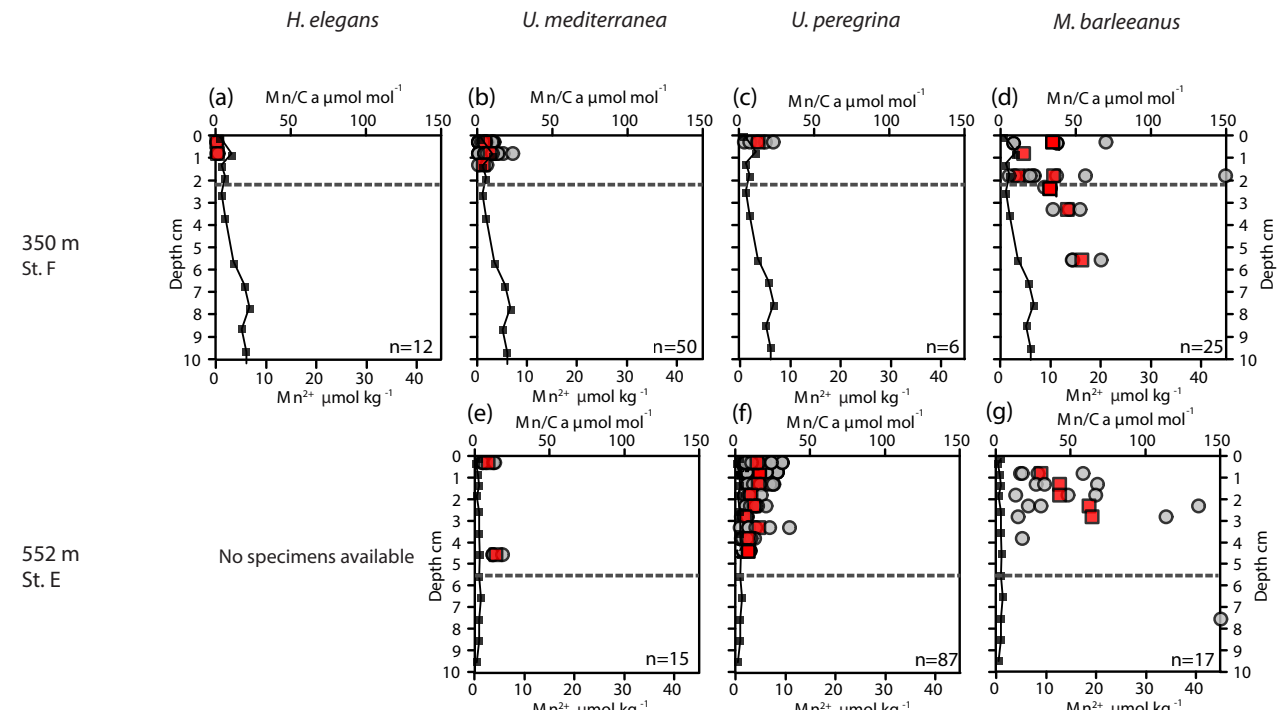

(g) $\mathrm{Mn} / \mathrm{Ca} \mu \mathrm{mol} \mathrm{mol}$
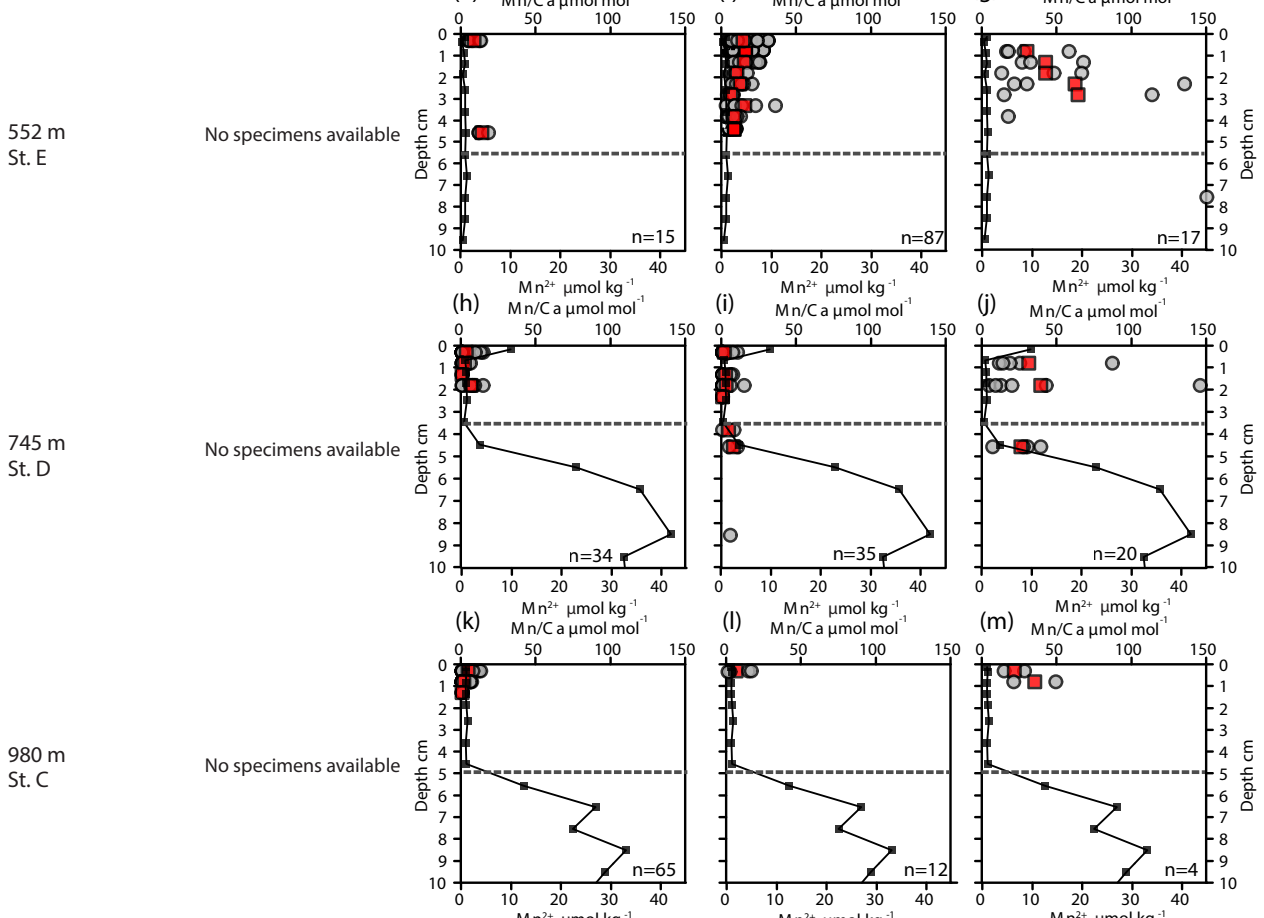

(m) $\begin{array}{r}\mathrm{Mn}^{2+} \mu \mathrm{mol} \mathrm{kg}^{-1} \\ \mathrm{Mn} / \mathrm{Ca} \mu \mathrm{mol} \mathrm{mol}^{-1}\end{array}$
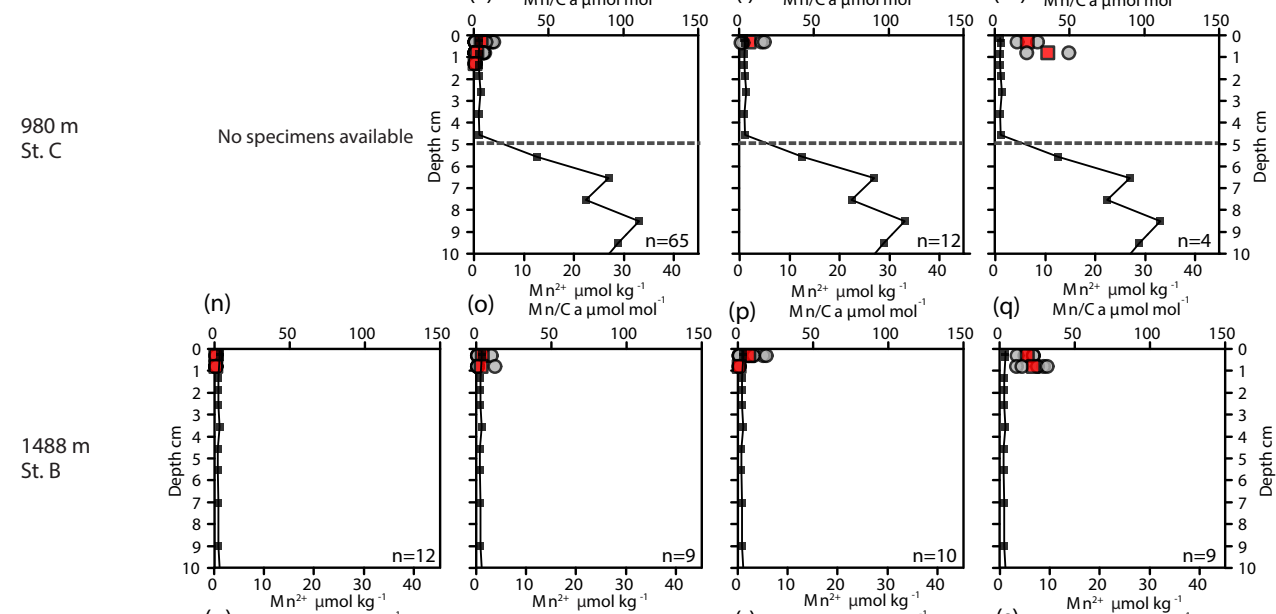

(o) $\mathrm{Mn} / \mathrm{Ca} \mu \mathrm{mol} \mathrm{mol}$

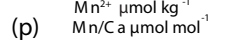

(q) $\mathrm{Mn} / \mathrm{Ca} \mathrm{amol} \mathrm{mol}^{2+}$
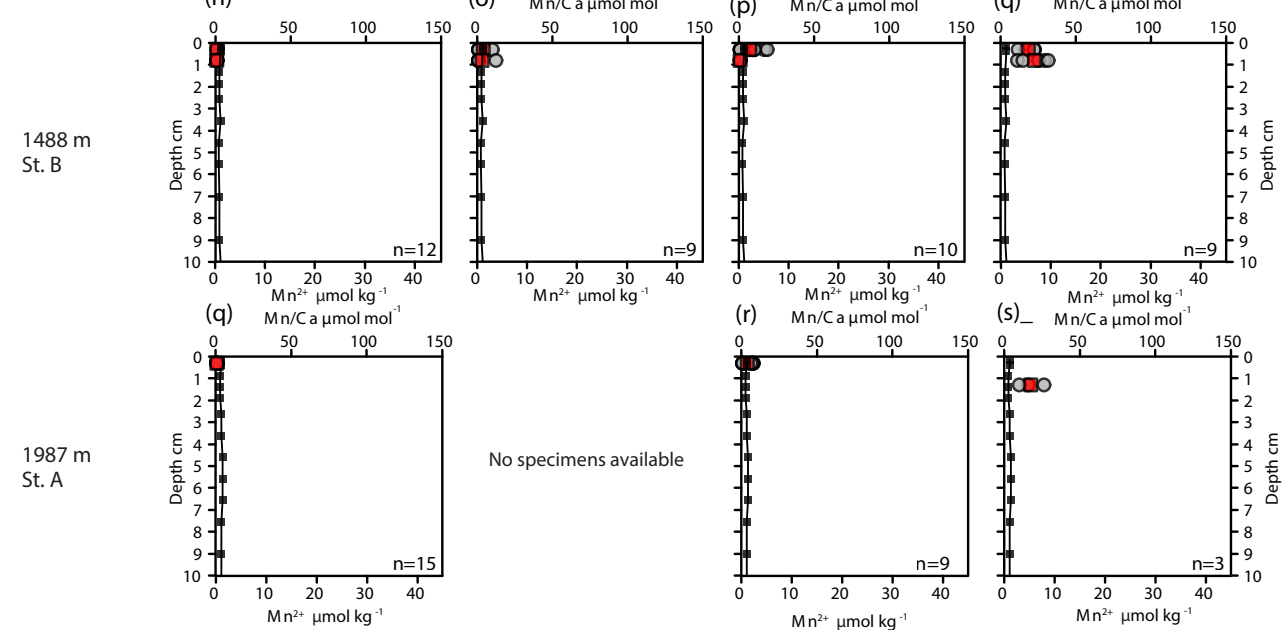

Figure 3. Plots of $\mathrm{Mn} / \mathrm{Ca}\left(\mu \mathrm{mol} \mathrm{mol}{ }^{-1}\right)$ measured in living (stained) Hoeglundina elegans, Uvigerina mediterranea, Uvigerina peregrina, and Melonis barleeanus. Individual analyses are plotted (grey circles) alongside average values for a given depth in the sediment (red squares). Pore water $\mathrm{Mn}^{2+}\left(\mu \mathrm{mol} \mathrm{kg}{ }^{-1}\right)$ profiles (black line) are plotted for all stations. The dashed grey line indicates the oxygen penetration depth (OPD). 
Table 4. Relative standard deviation (\% RSD) of intraindividual values in $\mathrm{Mn} / \mathrm{Ca}$ within four species of benthic foraminifera $(H$. elegans, U. mediterranea, U. peregrina, and M. barleeanus).

\begin{tabular}{lrrrr}
\hline Element & $\begin{array}{r}\text { H. elegans } \\
\text { \% RSD }\end{array}$ & $\begin{array}{r}\text { U. mediterranea } \\
\text { \% RSD }\end{array}$ & $\begin{array}{r}\text { U. peregrina } \\
\text { \% RSD }\end{array}$ & $\begin{array}{r}\text { M. barleeanus } \\
\text { \% RSD }\end{array}$ \\
\hline $\mathrm{Mn}$ & 21 & 23 & 20 & 51 \\
\hline
\end{tabular}

compares between species. All ICP-MS measurements are included and as such represent both intraindividual and interindividual variation.

\section{Results}

\subsection{Pore water data}

Pore water dissolved manganese $\left(\mathrm{Mn}^{2+}\right)$ concentrations were measured at all six stations. Manganese concentrations increase below the oxygen penetration depth at stations $\mathrm{C}$ and $\mathrm{D}$ (Fig. 3), with the highest in-sediment $\mathrm{Mn}^{2+}$ concentrations reached at station D. At stations $\mathrm{E}$ and $\mathrm{F}$ manganese concentrations remain low after crossing the oxygen penetration depth. At stations A and B the oxygen penetration depth and $\mathrm{MnO}_{2} / \mathrm{Mn}^{2+}$ redox boundary are deeper than $10 \mathrm{~cm}$. Dissolved inorganic carbon (DIC) and total alkalinity (TA) were measured at stations E, C, and B (Fig. 4). At stations D, $\mathrm{C}$, and E, DIC concentrations in the top $10 \mathrm{~cm}$ have a similar range (2350-2700 $\mu \mathrm{mol} \mathrm{kg} \mathrm{kg}^{-1}$ ). The DIC profile at station B has a narrower range from $2400-2550 \mu \mathrm{mol} \mathrm{kg}{ }^{-1}$. Total alkalinity values range from $3242 \mu \mathrm{mol} \mathrm{kg}{ }^{-1}$ at station $\mathrm{E}$ to a minimum of $2774 \mu \mathrm{mol} \mathrm{kg} \mathrm{kg}^{-1}$ at station B. Carbonate ion concentrations $\left[\mathrm{CO}_{3}^{2-}\right]$ were derived based on TA and DIC values. The $\left[\mathrm{CO}_{3}^{2-}\right]$ profiles were relatively similar (Fig. 4) for stations E, C, and B. Values for all three stations ranged from a maximum of $419 \mu \mathrm{mol} \mathrm{kg}-1$ at station $\mathrm{E}$ to a minimum of $192 \mu \mathrm{mol} \mathrm{kg}{ }^{-1}$ at station C (Fig. 4).

\subsection{Mn / Ca data}

\subsubsection{Intraindividual variability}

For most species some $\mathrm{Mn} / \mathrm{Ca}$ analyses were below the detection limit, except for M. barleeanus, which contained measurable quantities of $\mathrm{Mn}$ in all shells analyzed. This was most evident for $H$. elegans, for which all but three $\mathrm{Mn} / \mathrm{Ca}$ measurements were below the detection limit (DL). Uvigerina peregrina had a wider range of $\mathrm{Mn} / \mathrm{Ca}$ values than U. mediterranea. Melonis barleeanus exhibited the largest range of $\mathrm{Mn} / \mathrm{Ca}$ values of the four studied species (Fig. 5 and Table 5). For all species except $H$. elegans, the results are somewhat skewed towards higher values.

\subsubsection{Foraminiferal Mn / Ca variation across a depth transect}

A trend of decreasing manganese incorporation with increasing water depth $(350-1987 \mathrm{~m})$ is most clearly visible in $M$. barleeanus (Fig. 6), except that the maximum values are observed at station E at $552 \mathrm{~m}$. Melonis barleeanus shows the highest $\mathrm{Mn} / \mathrm{Ca}$ values and the largest $\mathrm{Mn} / \mathrm{Ca}$ variability. Station E registers the broadest $\mathrm{Mn} / \mathrm{Ca}$ variability, which decreases with increasing water depth. U. peregrina also exhibits the largest variability in $\mathrm{Mn} / \mathrm{Ca}$ values at station E. For $U$. peregrina, $\mathrm{Mn}^{2+}$ incorporation decreases from 350 to $1987 \mathrm{~m}$, except for station D (745 m), where Mn / Ca values (between the 10th and 90th percentile) are approximately equivalent to those at station A (350 m; Fig. 6). For $U$. mediterranea a trend of decreasing $\mathrm{Mn}$ incorporation with increasing depth is found in specimens of $U$. mediterranea from the sediments at 552,745 , and $980 \mathrm{~m}$. The highest values are reached at the shallowest station $(350 \mathrm{~m})$. Station $\mathrm{E}$ is also marked by the highest minimum $\mathrm{Mn} / \mathrm{Ca}$ values for $U$. mediterranea. At station A only two $U$. mediterranea measurements are above the detection limit. Hoeglundina elegans shells from three stations (350, 1488, and $1987 \mathrm{~m}$ ) were analyzed; however, all but three measurements were below the detection limit (Fig. 6). These slightly elevated values were recorded at the shallowest station (station F). These $\mathrm{Mn} / \mathrm{Ca}$ values are still very low compared to ranges in $\mathrm{Mn} / \mathrm{Ca}$ values observed for the other species (Fig. 6).

Variability in $\mathrm{Mn} / \mathrm{Ca}$ increases together with the overall $\mathrm{Mn} / \mathrm{Ca}$ concentration within benthic foraminiferal species (Table 4). This suggests that even at those stations and depth levels at which the highest Mn concentrations are recorded, individuals with relatively low amounts of $\mathrm{Mn}$ in their calcitic test were found. Comparing relative standard deviations as a measure of the inter-specimen variability for the different stations and species suggests that with increasing Mn concentration for M. barleeanus and U. mediterranea variability increases, whereas for $U$. peregrina it decreases.

\subsubsection{In-sediment variation}

For most species Mn / Ca values are more or less constant with in-sediment depth (Fig. 3). However, M. barleeanus shows increasing $\mathrm{Mn} / \mathrm{Ca}$ values with in-sediment depth. This is most apparent at the shallowest station (station F; $350 \mathrm{~m}$ ) (Fig. 3d ).

\section{Discussion}

Incorporation of $\mathrm{Mn}$ in benthic foraminiferal carbonate depends both on foraminiferal ecology and early diagenesis in sediments. Although other factors such as temperature, sea water carbonate chemistry, and growth rate might also affect the uptake of $\mathrm{Mn}$ in the shell carbonate (Koho et al., 2017), these effects are most likely several orders of mag- 

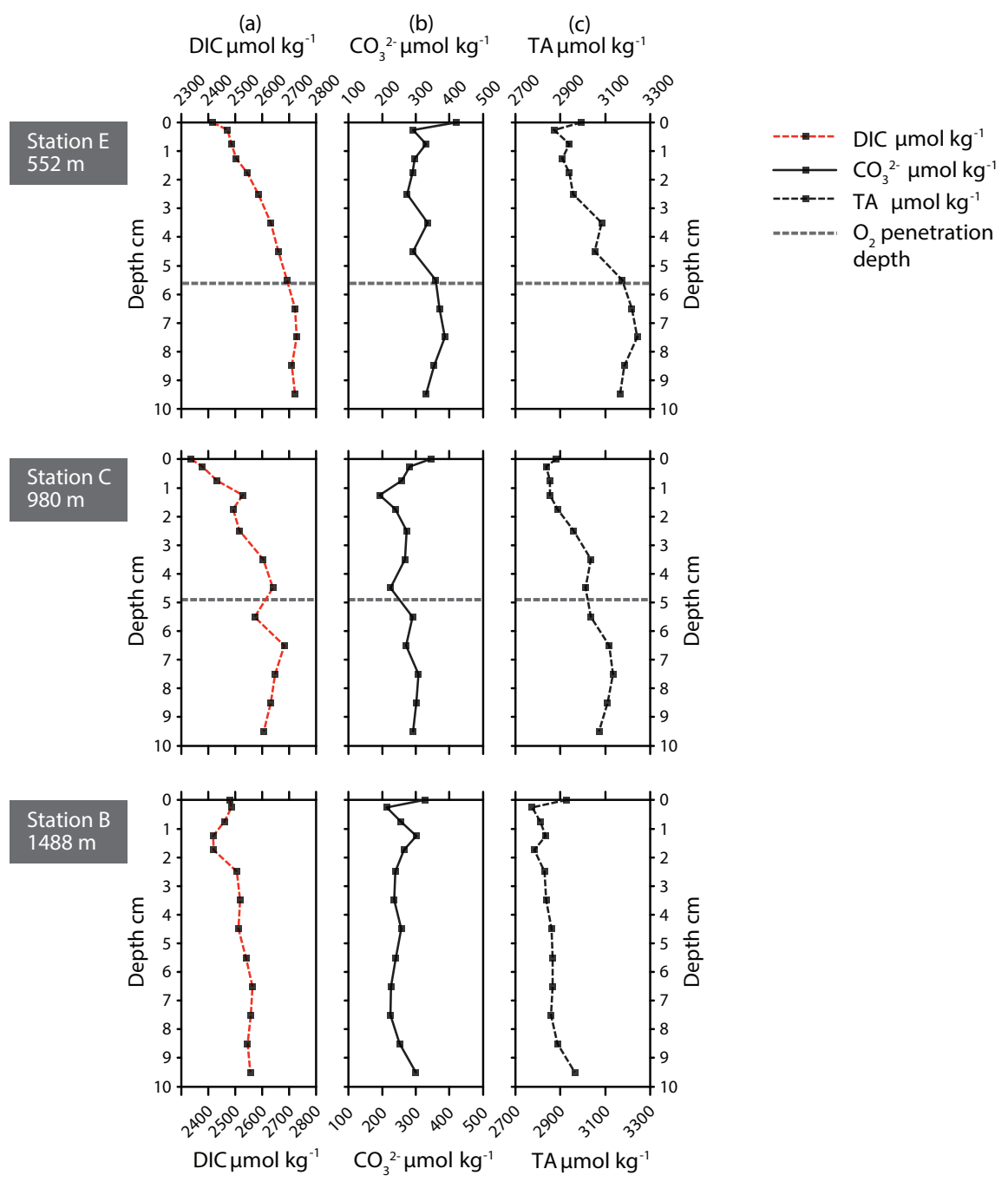

Figure 4. Carbonate chemistry parameters for stations E, C, and B. (a) Dissolved inorganic carbon (DIC), (b) $\left[\mathrm{CO}_{3}^{2-}\right]$ in $\mu \mathrm{mol} \mathrm{kg}^{-1}$, and (c) total alkalinity (TA) in $\mu \mathrm{mol} \mathrm{kg}^{-1}$.

nitude smaller compared to the large range in dissolved $\mathrm{Mn}$ in pore water. Since pore water $\mathrm{Mn}$ is the dominant factor controlling Mn incorporation, studies must account for ecological controls, like foraminiferal depth habitat preference, and for geochemical controls like oxygen concentrations and organic-matter fluxes (Koho et al., 2015; De Lange, 1986; Reichart et al., 2003). The fact that this study was based on living foraminifera circumvents potential complications due to Mn-rich coatings. Such coatings would likely not affect the aragonitic shell of $H$. elegans (Ní Fhlaithearta et al., 2010), but might interfere when analyzing fossil calcite shells. Still, a spatially resolved analytical technique like LAICP-MS allows for the detection of such coatings also in fossil specimens.

\subsection{Impact of redox conditions and foraminiferal habitat preference on $\mathrm{Mn}$ incorporation}

In general, the flux of organic matter arriving at the seafloor decreases with increasing water depth due to ongoing degradation during settling (Arndt et al., 2013, and references therein). Consequently, redox boundaries within the sediment generally also deepen as a function of water depth as oxygen consumption in the sediment decreases. Such a fundamental organic matter-depth relation is in line with the much deeper oxygen penetration depths at stations A and B compared to the more shallow stations. At station $\mathrm{F}$ the relative shallow oxygen penetration depth observed is in line with its relatively shallow water depth, although the organic matter that arrives here at the seafloor apparently undergoes winnowing (Fontanier et al., 2008). The organic matter along the transect studied is concentrated at a so-called depocenter, 


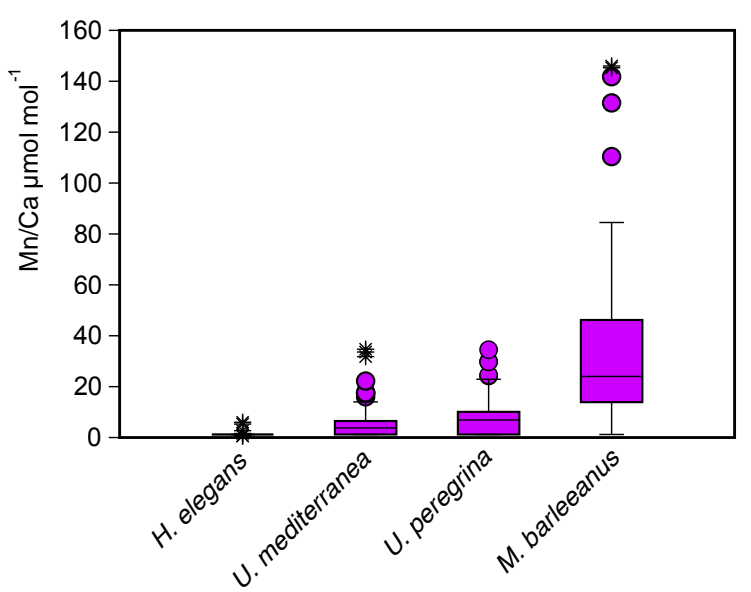

Figure 5. Box plots describing the distribution of $\mathrm{Mn} / \mathrm{Ca}$ values measured in living (stained) individuals of Hoeglundina elegans, Uvigerina mediterranea, Uvigerina peregrina, and Melonis barleeanus. The box represents all values between the 25th and 75th percentile. The dissection line through the box denotes the median. The whiskers are drawn from the top of the box up to the largest data point less than 1.5 times the box height from the box and similarly below the box. Values outside the whiskers are shown as circles, and values further than 3 times the box height are denoted as stars.

which largely coincides with the depths of stations C and D (Fontanier et al., 2008). As bottom waters at all stations are well oxygenated, organic-matter concentration can be considered the main control for redox conditions at stations $\mathrm{F}-$ A, with the amount of organic matter arriving at the seabed being regulated by water depth and sedimentary processes, such as focusing versus winnowing.

At stations $\mathrm{C}, \mathrm{D}$, and $\mathrm{F}$, the oxygen penetration depth and the $\mathrm{Mn}^{2+}$ redox boundaries are at the same depth, as expected. Station F shows the shallowest OPD of all stations, although the organic-matter concentration is relatively low. One explanation for this observation is that a lower porosity at $\mathrm{F}(56 \%$ versus $76 \%$ and $79 \%$ at stations $\mathrm{D}$ and $\mathrm{E}$, respectively) impedes oxygen diffusion through the sediment. Alternatively, the pore water profile reflects an earlier organic-matter deposition event, with this organic matter being largely consumed at the time of sampling. The pore water profiles require more time to re-equilibrate to the new conditions (Burdige and Gieskes, 1983). At station E there is a mismatch between oxygen penetration depth and the $\mathrm{Mn}^{2+}$ redox boundary, as the $\mathrm{Mn}^{2+}$ redox boundary is considerably deeper than the OPD. Although this is in line with the observed higher bioirrigation at this station (Fontanier et al., 2008), this might reflect nonequilibrium conditions as well.

The vertical distribution of benthic foraminiferal species varies between stations, in accordance with organic-matter concentrations and redox zonation, which is consistent with the TROX model (Jorissen et al., 1995; Fontanier et al., 2008). In the case of a shallower redox zone, infaunal ben- thic foraminifera biomineralize in contact with Mn-enriched pore water, with the highest dissolved manganese concentrations occurring just below the oxygen penetration depth at all stations, except for station E $(552 \mathrm{~m})$. This is in contrast to low bottom-water oxygen environments often studied in the context of proxy development studies, in which pore water $\mathrm{Mn}^{2+}$ is released from the pore water (Koho et al., 2015, 2017; Mangini et al., 2001).

The species studied here cover the range of shallow infauna to intermediate infauna niches. Both Uvigerina mediterranea and M. barleeanus were found in the Gulf of Lions to occupy shallow to intermediate infaunal habitats, with $U$. peregrina having a somewhat shallower infaunal habitat (Fontanier et al., 2008). Hoeglundina elegans, a typically shallow infaunal species, is often found close to the sediment-water interface (Jorissen et al., 1998; Schönfeld 2001; Fontanier et al., 2002, 2008) and contains the lowest concentration of $\mathrm{Mn}$ in its test. Only at the shallowest station (350 m) do three specimens of $H$. elegans show concentrations above the detection level, with values still low compared to the values observed for the other species (Fig. 6). In the Bay of Biscay Reichart et al. (2003) also suggested that elevated $\mathrm{Mn}$ concentrations in $H$. elegans were confined to stations with oxygen-depleted bottom waters and/or with a shallow oxygen penetration depth. Uvigerina mediterranea and Uvigerina peregrina are also classed as shallow infaunal species; they are typically found within the top few centimeters of the sediment column (Fontanier et al., 2002, 2008). The average living depth $\left(\mathrm{ALD}_{10}\right)$ as calculated in Fontanier et al. (2008) is consistently shallower than the $\mathrm{ALD}_{10}$ for $U$. mediterranea. This is at odds with previous reports suggesting $U$. peregrina has a slightly deeper microhabitat than U. mediterranea (Fontanier et al., 2002, 2006). That $U$. peregrina has a deeper microhabitat is further supported by the usual distinct $2{ }^{13} \mathrm{C}$ offset in $U$. peregrina, which is more depleted compared to $U$. mediterranea (Schmiedl et al., 2004; Fontanier et al., 2002, 2006). The higher Mn / Ca values observed here for $U$. peregrina (Fig. 6) support the idea that it calcifies somewhat deeper in the sediment compared to U. mediterranea. Alternatively, U. peregrina may migrate downwards within burrows to track food resources, recording redox steepness (Loubere et al., 1995). This could highlight a disparity between the assumed living depth (the depth interval of recovery) and biomineralization depth of foraminifera. Still, this would also result in a higher variability of $\mathrm{Mn} / \mathrm{Ca}$ values at higher Mn / Ca levels, which is not observed. Hence, more likely the observed disparity between the geochemical signals incorporated into foraminiferal calcite and the depth of recovery in $U$. peregrina reflects opportunistic behavior, with calcification at a shallower insediment depth in response to more favorable conditions after, e.g., seasonal peaks in organic-matter fluxes (Accornero et al., 2003) when the OPD is close to the sediment-water interface. 

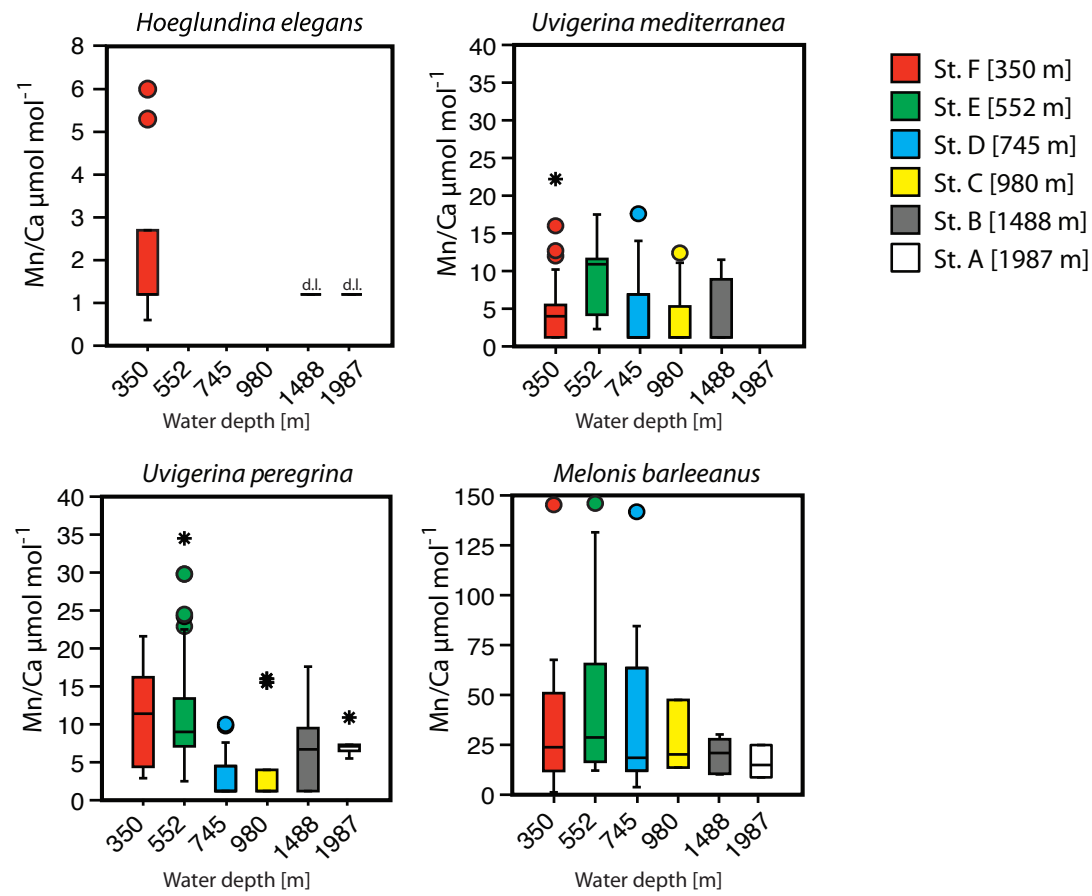

Figure 6. Box plots describing the distribution of $\mathrm{Mn} /$ Ca values across a depth transect (350-1987 m) measured in living (stained) individuals of Hoeglundina elegans, Uvigerina mediterranea, Uvigerina peregrina, and Melonis barleeanus. Note that the scale of the $y$ axis varies. The box represents all values between the 25th and 75th percentile with the whiskers extending less than 1.5 times the box height. The dissection line through the box denotes the median. Values outside the whiskers are shown as circles, and values further than 3 times the box height are denoted as stars. Detection limit (DL) for $H$. elegans is indicated when specimens have been measured but the signal was too low.
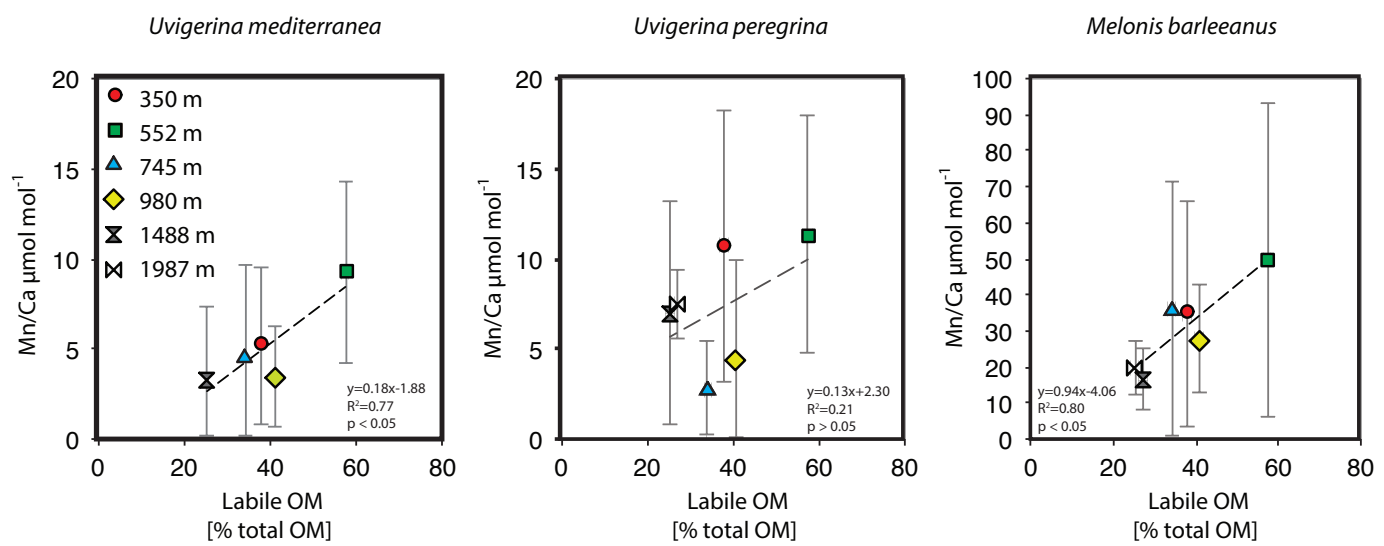

Figure 7. Plots of average $\mathrm{Mn} / \mathrm{Ca} \mu \mathrm{mol} \mathrm{mol}^{-1}$ versus labile organic matter (\% total organic matter).

Table 5. Relative standard deviation (\% RSD) of interindividual values in $\mathrm{Mn} / \mathrm{Ca}$ within four species of benthic foraminifera $(H$. elegans, U. mediterranea, U. peregrina, and M. barleeanus).

\begin{tabular}{lrrrr}
\hline Element & $\begin{array}{r}\text { H. elegans } \\
\% \text { RSD }\end{array}$ & $\begin{array}{r}\text { U. mediterranea } \\
\% \text { RSD }\end{array}$ & $\begin{array}{r}\text { U. peregrina } \\
\% \text { RSD }\end{array}$ & $\begin{array}{r}\text { M. barleeanus } \\
\% \text { RSD }\end{array}$ \\
\hline $\mathrm{Mn}$ & 400 & 125 & 87 & 97 \\
\hline
\end{tabular}

Melonis barleeanus, generally considered an intermediate infaunal species (Fontanier et al., 2002, 2008), contains the highest concentrations of $\mathrm{Mn}$ in its test, which is in line with the deepest habitat of the species studied here. Manganese incorporation in this species increases with increasing labile organic matter (Fig. 7a).

In summary, the habitat preference of the benthic foraminiferal species studied here is reflected in the $\mathrm{Mn} / \mathrm{Ca}$ 
Table 6. Manganese pore water-carbonate partition coefficient for foraminiferal species Uvigerina mediterranea, Uvigerina peregrina, and Melonis barleeanus.

\begin{tabular}{lrrr}
\hline & \multicolumn{3}{c}{ Partition coefficient $(D)^{*}$} \\
\cline { 2 - 4 } Station & U. mediterranea & U. peregrina & M. barleeanus \\
\hline E $(552 \mathrm{~m})$ & 1.7 & 1.8 & 7.0 \\
C $(980 \mathrm{~m})$ & 1.2 & - & 5.1 \\
B $(1488 \mathrm{~m})$ & 2.2 & 2.3 & 4.1 \\
\hline
\end{tabular}

* Pore water-carbonate partition coefficients were calculated using the average pore water $\mathrm{Mn} / \mathrm{Ca}\left(\mu \mathrm{mol} \mathrm{mol}^{-1}\right)$ measured above the oxygen penetration depth and the average carbonate $\mathrm{Mn} / \mathrm{Ca}\left(\mathrm{umol} \mathrm{mol}^{-1}\right)$ measured in $U$. mediterranea, $U$. peregrina, and $M$. barleeanus for all specimens recovered above the reported oxygen penetration depth (Fontanier et al., 2008).

values recorded in their tests. This is in contrast with other results showing lower $\mathrm{Mn} / \mathrm{Ca}$ values in foraminiferal tests with shallower redox fronts (Koho et al., 2015). This, however, critically depends on the Mn being released to the water column, which only occurs when the bottom waters are dysoxic. In the case of a seasonal organic-matter deposition event, an increase in Mn concentration in foraminiferal test carbonate would initially occur in the deeper and ultimately also in the more shallow calcifying foraminifera. This is in line with the conceptual TROXCHEM ${ }^{3}$ model, with the conditions studied here falling within the first stage of the temporal succession considered in the model. Bottom water remains well oxygenated $\left(\mathrm{O}_{2}\right.$ concentrations at the study area are 199-219 $\mu \mathrm{mol} \mathrm{L}^{-1}$; Fontanier et al., 2008) and organicmatter loading is controlling $\mathrm{Mn}^{2+}$ concentrations in the sediment. To what extent species are high in $\mathrm{Mn} / \mathrm{Ca}$ depends on living depth and opportunistic behavior.

At a given location, a benthic foraminiferal species depth preference or biomineralization depth is reflected in its average Mn / Ca value (Fig. 5). The trend across a depth transect shows a strong correlation with labile organic-matter concentrations in the surface sediments (Fig. 7). The strong correlation between labile organic matter (i.e., sedimentary lipid content) and $\mathrm{Mn}$ incorporation in the shallow and intermediate infaunal species $U$. mediterranea $\left(R^{2}=0.80, p<0.05\right)$ suggests that test $\mathrm{Mn}$ has potential as a proxy for detecting past labile organic-matter fluxes. Notably, M. barleeanus has a very strong correlation $(0.81)$, though this correlation lacks statistical significance $(p>0.05)$. In contrast, $U$. peregrina shows a correlation coefficient of only $0.45\left(R^{2}\right)$ between test $\mathrm{Mn}$ and labile organic matter. Uvigerina peregrina is reported to respond opportunistically to the concentration and quality of organic matter produced during bloom events (Fontanier et al., 2003; Koho et al., 2008; Barras et al., 2010). This response is in the form of increased reproduction and growth. Perhaps $U$. peregrina calcifies preferentially at shallower depths and therefore does not capture the full $\mathrm{Mn}^{2+}$ gradient.

At low oxygen concentrations $\mathrm{Mn}$ is released through the reduction of manganese (oxy)hydroxides. Here we show an increase in $\mathrm{Mn} / \mathrm{Ca}$ incorporation in several species, from shallow- to intermediate-depth infaunal habitats, as a function of oxygen penetration depth. Such a correlation agrees with studies by Ní Fhlaithearta et al. (2010) and McKay et al. (2015) from a down-core record of $\mathrm{Mn} / \mathrm{Ca}$. elegans during the formation of sapropel (S1) in the eastern Mediterranean and a paleoproductivity study of an upwelling system in the NE Atlantic, respectively. Here, a comparison of $\mathrm{Mn}$ (oxy)hydroxides in the sediment and foraminiferal $\mathrm{Mn}^{2+}$ showed that $\mathrm{Mn}^{2+}$ incorporation in an epifaunal to shallow infaunal species was higher during times of enhanced $\mathrm{Mn}^{2+}$ remobilization and hence higher pore water $\mathrm{Mn}^{2+}$. Such a correlation, however, requires that the bottom waters remain somewhat oxygenated to retain the dissolved $\mathrm{Mn}^{2+}$ in the pore water. With dysoxic bottom waters $\mathrm{Mn}^{2+}$ escapes the pore water and foraminiferal $\mathrm{Mn} / \mathrm{Ca}$ values decrease (Koho et al., 2015). However, with high organic-matter deposition, which might be concentrated in events, foraminiferal species living at or close to the sediment-water interface may also show elevated Mn concentrations.

In addition to the changes observed here, biomineralization could affect $\mathrm{Mn}^{2+}$ incorporation. In a controlled laboratory study by Munsel et al. (2010) Mn incorporation in Ammonia tepida increased with increasing $\mathrm{Mn}^{2+}$ concentrations in the culture water and the partition coefficient was well above 1. The lack of an appreciable discrimination argues against a major biomineralization impact on $\mathrm{Mn}^{2+}$ partitioning. Recently, however, Barras et al. (2018), also using controlled growth experiments, showed that Mn partitioning in B. marginata differs from that in A. tepida, with that in $B$. marginata being close to 1 and that of $A$. tepida being 4 times lower. Interspecific differences are considerable and hence an impact of biomineralization on $\mathrm{Mn}$ incorporation cannot be disregarded.

In summary, Mn incorporation seems primarily controlled by pore water conditions in close proximity to the test, biomineralization, and with a secondary control determined by the ability of a foraminifer to seasonally calcify and migrate within the sediment.

\subsection{Pore water Mn dynamics and foraminiferal migration within the sediment}

Manganese is incorporated in foraminiferal carbonate with a partition coefficient $(D)$ close to 1 or somewhat lower (Munsel et al., 2010; Barras et al., 2018). We calculated Mn partition coefficients for $U$. mediterranea, U. peregrina, and $M$. barleeanus at stations E, C, and B (Table 6) based on average $\mathrm{Mn} / \mathrm{Ca}_{\text {foram }}$ and average $\mathrm{Mn} / \mathrm{Ca}_{\text {pore water values }}$ found above the $\mathrm{Mn}^{2+}-\mathrm{MnO}(\mathrm{H})$ redox boundary. Calculated $D_{\text {Mn }}$ agrees with the previously reported $D_{\text {Mn }}$ by Munsel et al. (2010), with values varying between $\sim 1$ and 2 for $U$. mediterranea and $U$. peregrina. The Mn partition coefficient for Melonis barleeanus ranges from $\sim 4-7$. The partition coefficient for this species most likely reflects its capacity to 


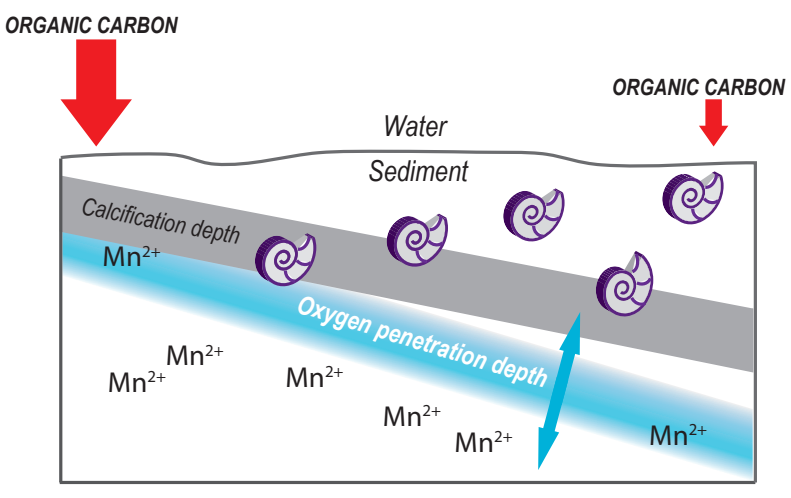

Figure 8. Schematic diagram of a shallow infaunal and intermediate infaunal benthic foraminifera and their spatial relationship with the sediment redox boundaries, migration zone, ALD, and calcification depth.

calcify under dysoxic conditions, close to or even below the oxygen penetration depth. Still, this calculation is based on two assumptions: (1) the depth foraminifera are recovered from during sampling corresponds with the average depth of calcification, and (2) variation in pore water is limited. Establishing species-specific Mn partitioning coefficients using culture experiments might, however, be needed for unlocking the full potential of this proxy (Barras et al., 2018).

A foraminifer calcifying within a steep $\mathrm{Mn}^{2+}$ gradient is exposed to a higher range of $\mathrm{Mn}^{2+}$ concentrations (over a fixed depth interval) compared to specimens living along a more gradual $\mathrm{Mn}^{2+}$ concentration gradient. Since foraminifera can migrate through the sediment as a response to food availability and oxygen concentrations (Alve and Bernhard 1995; Gross, 2000), not only the slope of the Mn gradient, but also the in-sediment depth range (microhabitat) of the foraminifer in relation to the $\mathrm{Mn}$ redox boundary, should be considered (Fig. 8). Although the analysis of foraminiferal test $\mathrm{Mn} / \mathrm{Ca}$ is challenging, which adds to the inter-specimen variability, we observe systematic differences between species in Mn / Ca variability. A shallow infauna species with a limited in-sediment range would be expected to exhibit lower variability than an intermediate infaunal species, which possibly migrates considerably in depth. This is exemplified at station F $(350 \mathrm{~m})$ where we note an increase in foraminiferal test $\mathrm{Mn} / \mathrm{Ca}$ variability at $2 \mathrm{~cm}$ of depth, consistent with the oxygen penetration depth at that station (Fig. 3). Moreover, the variability in $\mathrm{Mn} / \mathrm{Ca}$ values increases towards higher $\mathrm{Mn} / \mathrm{Ca}$ values. This is in line with the depth habitat of M. barleeanus being consistently deeper and this species traveling more actively through the redox zones than $U$. mediterranea or $U$. peregrina. Nitrate respiration could be the mechanism allowing this dynamic behavior by $M$. barleeanus in the intermediate depth habitat. However, Pina-Ochao et al. (2010), studying denitrification in foraminifera, report nitrate storage in all three species mentioned here. Notably, nitrate storage in M. barleeanus is lower than $U$. mediterranea and $U$. peregrina. Alternatively, $M$. barleeanus thrives in habitats with varying oxygenation and hence also varying Mn levels, whereas the stable but high $\mathrm{Mn} / \mathrm{Ca}$ values in the uvigerinids are related to their opportunistic behavior.

With a redox-sensitive element such as $\mathrm{Mn}$ in a dynamic geochemical environment, it is not surprising that foraminifera exhibit high interindividual variability in their $\mathrm{Mn} / \mathrm{Ca}$ incorporation. Benthic foraminifera reside in a 3-D geochemical mosaic, as reflected by a large spread of Mn values, in addition to undergoing substantial temporal variability. Still, using Mn / Ca as a potential proxy for redox conditions or primary productivity seems promising, as established ecological characteristics of species are reflected by differences in Mn incorporation. Apparently the large variability on both spatial and temporal scales averages out, making Mn a promising proxy for paleo-redox and organic-matter flux.

\section{Conclusions}

This study investigates the link between benthic foraminiferal habitat preferences and manganese incorporation in their tests. Manganese incorporation increases with bottom-arriving labile organic-matter content driven by enhanced oxygen demand. This results in a more shallow oxygen penetration depth with enhanced dissolved Mn levels immediately below it. Shallow infaunal species calcify under lower concentrations of $\mathrm{Mn}$ compared to intermediate infauna, in line with their depth preference. Their depth habitat is related to in-sediment changes in redox conditions. However, these distributions do not necessarily vary synchronously with changes in redox zonation as illustrated by the Mn / Ca variability in their tests (Fig. 8). The latter reflects the $\mathrm{Mn} / \mathrm{Ca}$ pore water composition, which itself is directly related to reactive organic-matter concentration and redox conditions. The foraminiferal $\mathrm{Mn} / \mathrm{Ca}$ ratio and inter-specimen variability therefore provide information on past Mn cycling within the sediment. Consequently, the foraminiferal $\mathrm{Mn} / \mathrm{Ca}$ ratio is a potential proxy for bottom-water oxygenation and organic-matter fluxes.

Data availability. The data on which this publication is based can be found through the following: https://doi.org/10.4121/uuid:9f44c16a-ccc1-4bef-8e98d01320797271 (Reichart et al., 2018).

Author contributions. SNF carried out the experiments and analyses, CF organized the expedition, AM and PA provided porewater analyses, ADB collected samples during the expedition, MBF and DG provided the laser ablation analyses at ETH, and GJL and GJR designed the study. All authors helped with data interpretation and writing the paper. 
Competing interests. The authors declare that they have no conflict of interest.

Acknowledgements. We thank the captain and crew of the N/O Téthys 2 (CNRS-INSU) for their assistance during the BEHEMOTH campaign. We acknowledge the technical assistance given by Christine Chabaud, Mélissa Gaultier, Sophie Terrien, and Gérard Chabaud from Angers and Bordeaux University. We thank Serge Berné and Laetitia Maltese (Ifremer) for providing us with maps of the study area and Xavier Durrieu de Madron (Perpignan University) for discussions about water column structure. Helen de Waard (LA-ICP-MS) and Karoliina Koho (SEM) (Utrecht University) are acknowledged for their laboratory assistance. The associate editor and two anonymous reviewers are acknowledged for their helpful comments. The Darwin Center for Biogeosciences provided partial funding for this project. This paper contributes to the Netherlands Earth Systems Science Center (NESSC; http://www.nessc.nl, last access: 23 October 2018).

Edited by: Hiroshi Kitazato

Reviewed by: two anonymous referees

\section{References}

Accornero, A., Picon, P., De Bovée, F., Charrière, B., and Buscail, R.: Organic carbon budget at the sediment-water interface on the Gulf of Lions continental margin, Cont. Shelf Res., 23, 79-92, 2003.

Alve, E. and Bernhard, J. M.: Vertical migratory response of benthic foraminifera to controlled oxygen concentrations in an experimental mesocosm, Oceanographic Literature Review, 9, 137$151,1995$.

Arndt, S., Jørgensen, B. B., LaRowe, D. E., Middelburg, J. J., Pancost, R. D., and Regnier, P.: Quantifying the degradation of organic matter in marine sediments: A review and synthesis, Earth-Sci. Rev., 123, 53-86, https://doi.org/10.1016/j.earscirev.2013.02.008, 2013.

Barnett, P. R. O., Watson, J., and Connely, D.: A multiple corer for taking virtually undisturbed sample from shelf, bathyal and abyssal sediments, Oceanol. Acta, 7, 399-408, 1984.

Barras, C., Fontanier, C., Jorissen, F., and Hohenegger, J.: A comparison of spatial and temporal variability of living benthic foraminiferal faunas at $550 \mathrm{~m}$ depth in the Bay of Biscay, Micropaleontology, 56, 275-295, 2010.

Barras, C., Mouret, A., Nardelli, M.P., Metzger, E., Petersen, J., La, C., Filipsson, H. L., and Jorissen, F.: Experimental calibration of manganese incorporation in foraminiferal calcite, Geochim. Cosmochim. Ac., 237, 49-64, 2018.

Boyle, E. A.: Manganese carbonate overgrowths on foraminifera tests, Geochim. Cosmochim. Ac., 47, 1815-1819, 1983.

Burdige, D. J. and Gieskes, J. M. : A pore water/solid phase diagenetic model for manganese in marine sediments, Am. J. Sci., 283, 29-47, 1983.

De Lange, G. J.: Early diagenetic reactions in interbedded pelagic and turbiditic sediments in the Nares Abyssal Plain (western North Atlantic): Consequences for the composition of sediment and interstitial water, Geochim. Cosmochim. Ac., 50, 25432561, 1986.

Dueñas-Bohórquez, A., Rocha, R., Kuroyanagi, A., de Nooijer, L., Bijma, J., and Reichart, G. J.: Interindividual variability and ontogenetic effects on $\mathrm{Mg}$ and $\mathrm{Sr}$ incorporation in the planktonic foraminifer Globigerinoides sacculifer, Geochim. Cosmochim. Ac., 75, 520-532, 2011.

Elderfield, H., Yu, J., Anand, P., Kiefer, T., and Nyland, B.: Calibrations for benthic foraminiferal $\mathrm{Mg} / \mathrm{Ca}$ paleothermometry and the carbonate ion hypothesis, Earth Planet. Sc. Lett., 250, 633649, 2006.

Fontanier, C., Jorissen, F. J., Licari, L., Alexandre, A., Anschutz, P., and Carbonel, P.: Live benthic foraminiferal faunas from the Bay of Biscay: faunal density, composition, and microhabitats, Deep-Sea Res. Pt. I, 49, 751-785, 2002.

Fontanier, C., Jorissen, F. J., David, C., Anschutz, P., Chaillou, G., and Lafon, V.: Seasonal and interannual variability of benthic foraminiferal faunas at $550 \mathrm{~m}$ depth in the Bay of Biscay, DeepSea Res. Pt. 1, 50, 457-494, 2003.

Fontanier, C., Mackensen, A., Jorissen, F. J., Anschutz, P., Licari, L., and Griveaud, C.: Stable oxygen and carbon isotopes of live benthic foraminifera from the Bay of Biscay: Microhabitat impact and seasonal variability, Mar. Micropaleontol., 58, 159-183, 2006.

Fontanier, C., Jorissen, F. J., Lansard, B., Mouret, A., Buscail, R., Schmidt, S., Kerhervé, P., Buron, F., Zaragosi, S., Hunault, G., Ernoult, E., Artero, C., Anschutz, P., and Rabouille, C.: Live foraminifera from the open slope between Grand Rhône and Petit Rhône Canyons (Gulf of Lions, NW Mediterranean), Deep-Sea Res. Pt. I, 55, 1532-1553, 2008.

Froelich P. N., Klinkhammer G. P., Bender M. L., Luedtke N. A., Heath G. R., Cullen D., Dauphin P., Hammond D., Hartman B., and Maynard V.: Early oxidation of organic matter in pelagic sediments of the eastern equatorial Atlantic: suboxic diagenesis, Geochim. Cosmochim. Ac., 43, 1075-1090, 1979.

Glock, N., Eisenhauer, A., Liebetrau, V., Wiedenbeck, M., Hensen, C., and Nehrke, G.: EMP and SIMS studies on $\mathrm{Mn} / \mathrm{Ca}$ and $\mathrm{Fe} / \mathrm{Ca}$ systematics in benthic foraminifera from the Peruvian OMZ: a contribution to the identification of potential redox proxies and the impact of cleaning protocols, Biogeosciences, 9, 341359, https://doi.org/10.5194/bg-9-341-2012, 2012.

Groeneveld, J. and Filipsson, H. L.: Mg / Ca and Mn / Ca ratios in benthic foraminifera: the potential to reconstruct past variations in temperature and hypoxia in shelf regions, Biogeosciences, 10 , 5125-5138, https://doi.org/10.5194/bg-10-5125-2013, 2013.

Gross, O.: Influence of temperature, oxygen and food availability on the migrational activity of bathyal benthic foraminifera: evidence by microcosm experiments, in: Life at Interfaces and Under Extreme Conditions, Springer Netherlands, 123-137, 2000.

Hintz, C. J., Shaw, T. J., Chandler, G. T., Bernhard, J. M., McCorkle, D. C., and Blanks, J. K.: Trace/minor element?: calcium ratios in cultured benthic foraminifera. Part I: Inter-species and inter-individual variability, Geochim. Cosmochim. Ac., 70, 1952-1963, 2006.

Jochum, K. P., Weis, U., Stoll, B., Kuzmin, D., Yang, Q., Raczek, I., Jacob, D. E., Stracke, A., Birbaum, K., Frick, D. A., Gunther, D., Enzweiler, J.: Determination of Reference Values for NIST SRM 610-617 Glasses Following ISO Guidelines, Geostand. Geoanal. Res., 35, 397-421, 2011. 
Jorissen, F. J., de Stigter, H. C., and Widmark, J. G. V: A conceptual model explaining benthic foraminiferal microhabitats, Mar. Micropaleontol., 26, 3-15, 1995.

Jorissen, F. J., Wittling, I., Peypouquet, J. P., Rabouille, C., and Relexans, J. C.: Live benthic foraminiferal faunas off Cape Blanc, NW-Africa: Community structure and microhabitats, Deep-Sea Res. Pt. I, 45, 2157-2188, 1998.

Koho, K. A., Langezaal, A. M., van Lith, Y. A., Duijnstee, I. A. P., and van der Zwaan, G. J.: The influence of a simulated diatom bloom on deep-sea benthic foraminifera and the activity of bacteria: A mesocosm study, Deep-See Res. Pt. I, 55, 696-719, 2008.

Koho, K. A., Piña-Ochoa, E., Geslin, E., and Risgaard-Petersen, N.: Vertical migration, nitrate uptake and denitrification: Survival mechanisms of foraminifers (Globobulimina turgida) under low oxygen conditions, FEMS Microbiol. Ecol., 75, 273-283, 2011.

Koho, K. A., de Nooijer, L. J., and Reichart, G. J.: Combining benthic foraminiferal ecology and shell $\mathrm{Mn} / \mathrm{Ca}$ to deconvolve past bottom water oxygenation and paleoproductivity, Geochim. Cosmochim. Ac., 165, 294-306, 2015.

Koho, K. A., de Nooijer, L. J., Fontanier, C., Toyofuku, T., Oguri, K., Kitazato, H., and Reichart, G.-J.: Benthic foraminiferal $\mathrm{Mn} / \mathrm{Ca}$ ratios reflect microhabitat preferences, Biogeosciences, 14, 3067-3082, https://doi.org/10.5194/bg-14-3067-2017, 2017.

Lea, D. and Boyle, E.: Barium content of benthic foraminifera controlled by bottom-water composition, Nature, 338, 751-753, 1989.

Lewis, E. and Wallace, D. W. R.: Program Developed for $\mathrm{CO}_{2}$ Systems Calculations, ORNL/CDIAC-105, Carbon Dioxide Information Analysis Centre, Oak Ridge National Laboratory US Department of Energy, Oak Ridge, Tennessee, 1998.

Loubere, P., Meyers, P., and Gary, A.: Benthic foraminiferal microhabitat selection, carbon isotope values, and association with larger animals: A test with uvigerina peregrina, J. Foramin. Res., 25, 83-95, 1995.

Mangini, A., Jung, M., and Laukenmann, S.: What do we learn from peaks of uranium and of manganese in deep sea sediments?, Mar. Geol., 177, 63-78, 2001.

McKay, C. L., Groeneveld, J., Filipsson, H. L., Gallego-Torres, D., Whitehouse, M. J., Toyofuku, T., and Romero, O. E.: A comparison of benthic foraminiferal $\mathrm{Mn} / \mathrm{Ca}$ and sedimentary $\mathrm{Mn} / \mathrm{Al}$ as proxies of relative bottom-water oxygenation in the low-latitude NE Atlantic upwelling system, Biogeosciences, 12, 5415-5428, https://doi.org/10.5194/bg-12-5415-2015, 2015.

Munsel, D., Kramar, U., Dissard, D., Nehrke, G., Berner, Z., Bijma, J., Reichart, G.-J., and Neumann, T.: Heavy metal incorporation in foraminiferal calcite: results from multi-element enrichment culture experiments with Ammonia tepida, Biogeosciences, 7, 2339-2350, https://doi.org/10.5194/bg-7-2339-2010, 2010.

Ní Fhlaithearta, S., Reichart, G.-J., Jorissen, F. J., Fontanier, C., Rohling, E. J., Thomson, J., and de Lange, G. J.: Reconstructing the seafloor environment during sapropel formation using benthic foraminiferal trace metals, stable isotopes, and sediment composition, Paleoceanography, 25, PA4225, https://doi.org/10.1029/2009PA001869, 2010.
Ní Fhlaithearta, S., Ernst, S. R., Nierop, K. G. J., de Lange, G. J., and Reichart, G.-J.: Molecular and isotopic composition of foraminiferal organic linings, Mar. Micropaleontol., 102, 69-78, 2013.

Nürnberg, D., Bijma, J., and Hemleben, C.: Assessing the reliability of magnesium in foraminiferal calcite as a proxy for water mass temperatures, Geochim. Cosmochim. Ac., 60, 803-814, 1996.

Pina-Ochoa, E., Hogslund, S., Geslin, E., Cedhagen, T., Revsbech, N. P., Nielsen, L. P., Schweizer, M., Jorissen, F., Rysgaard, S., and Risgaard-Petersen, N.: Widespread occurrence of nitrate storage and denitrification among Foraminifera and Gromiida, P. Natl. Acad. Sci. USA, 107, 1148-1153, 2010.

Reichart, G. J., Jorissen, F., Anschutz, P., and Mason, P. R. D.: Single foraminiferal test chemistry records the marine environment, Geology, 31, 355-358, 2003.

Reichart, G. J., Ní Fhlaithearta, S., Fontanier, C., Jorissen, F., Mouret, A., Dueñas-Bohórquez, A., Anschutz, P., Fricker, M. B., Günther, D., and de Lange, G. J.: Laser ablation Mn / Ca ratios of single foraminiferal shells from the Gulf of Lions, 4TU, Centre for Research Data, available at: https://doi.org/10.4121/uuid: 9f44c16a-ccc1-4bef-8e98-d01320797271, last access: 23 October 2018.

Risgaard-Petersen, N., Langezaal, A. M., Ingvardsen, S., Schmid, M. C., Jetten, M. S. M., Op Den Camp, H. J. M., Derksen, J. W. M., Piña-Ochoa, E., Eriksson, S. P., Nielsen, L. P., Revsbech, N. P., Cedhagen, T., and Van Der Zwaan, G. J.: Evidence for complete denitrification in a benthic foraminifer, Nature, 443, 93-96, 2006.

Rosenthal, Y., Morley, A., Barras, C., Katz, M. E., Jorissen, F., Reichart, G.-J., Oppo, D. W., and Linsley, Braddock. K.: Temperature calibration of $\mathrm{Mg} / \mathrm{Ca}$ ratios in the intermediate water benthic foraminifera Hyalinea Balthica, Geochem. Geophy. Geosy., 12, https://doi.org/10.1029/2010GC003333, 2011.

Schönfeld, J.: Benthic foraminifera and pore water oxygen profiles: A reassessment of species boundary conditions at the Western Iberian margin, J. Foramin. Res., 31, 86-107, 2001.

Schmiedl, G., Pfeilsticker, M., Hemleben, C., and Mackensen, A.: Environmental and biological effects on the stable isotope composition of recent deep-sea benthic foraminifera from the western Mediterranean Sea, Mar. Micropaleontol., 51, 129-152, 2004.

Van Cappellen, P. and Wang, Y.: Cycling of iron and manganese in surface sediments: A general theory for the coupled transport and reaction of carbon, oxygen, nitrogen, sulfur, iron, and manganese, Am. J. Sci., 296, 197-243, 1996.

Wang, Y. and Van Cappellen, P.: A multicomponent reactive transport model of early diagenesis: Application to redox cycling in coastal marine sediments, Geochim. Cosmochim. Ac., 60, 2993 3014, 1996.

Wit, J. C., de Nooijer, L. J., Barras, C., Jorissen, F. J., and Reichart, G. J.: A reappraisal of the vital effect in cultured benthic foraminifer Bulimina marginata on $\mathrm{Mg}$ / Ca values: assessing temperature uncertainty relationships, Biogeosciences, 9, 36933704, https://doi.org/10.5194/bg-9-3693-2012, 2012.

Yu, J. and Elderfield, H.: Benthic foraminiferal B / Ca ratios reflect deep water carbonate saturation state, Earth Planet. Sc. Lett., 258, 73-86, 2007. 